UDC 541.64+678-9

\author{
E.E. Ergozhin, B.R. Tausarova, R.K. Ashkeeva, L.M. Tugelbaeva* \\ Al -Farabi Kazakh National University, Republic of Kazakhstan, Almaty \\ "E-mail: tugelbaeva-leila@mail.ru
}

\title{
Complexing sorbents for wastewater purification
}

The new copolymer based on styrene and divinylbenzene with groups of nicotinamide and copolymers based on isomers methacryloylaminobenzoic acids with 2-methyl-5-vinylpyridine are obtained by chemical modification and radical copolymerization. The optimal conditions of synthesis were found out. Structure and properties of the initial compounds and copolymers based on them have been studied by IR spectroscopy and elemental analysis. The sorption properties of the synthesized polymers with respect to the ions of heavy and transition metals were investigated.

Key words: sorbent, chemical modification, radical copolymerization, complex forming ability, heavy metals, transitional metals, static exchange capacity.

Е.Е. Ерғожин, Б.Р.Таусарова, Р.К. Ашкеева, Л.М. Тугелбаева

Ағынды суларды тазалау үшін қолданылатын кешен құрайтын сорбенттер

Никотинамид топтары бар стирол мен дивинилбензол негізінде химиялық модификациялау әдісімен жаңа сополимер және радикалды сополимерлену әдісімен метакрилоиламинобензол қышқылдарының изомерлерінің 2-метил-5-винилпиридинмен жаңа сополимерлері алынды. Синтездеудің ең тиімді жағдайлары анықталды. Алғашқы қосылыстардың және олардың негізіндегі сополимерлердің құрылысы мен қасиеттері ИК-спектроскопия және элементті анализ әдістерімен анықталды. Алынған сополимердің ауыр және өтпелі металл иондарын сорып алу қабілеттілігі зерттелді.

Tүйін сөздер: сорбент, химиялық түрлендіру, радикалды сополимеризация, кешен түзу қабілеті, ауыр металдар, ауыспалы металдар, статикалық алмасу сыйымдылығы.

\section{Е.Е. Ергожин, Б.Р. Таусарова, Р.К. Ашкеева, Л.М. Тугелбаева}

Комплексообразующие сорбенты для очистки сточных вод

Методами химической модификации и радикальной сополимеризации получены новые сополимер на основе стирола и дивинилбензола с группами никотинамида и сополимеры на основе изомеров метакрилоиламинобензойных кислот с 2-метил-5-винилпиридином. Найдены оптимальные условия синтеза. Строение и свойства исходных соединений и сополимеров на их основе исследованы методами ИК-спектроскопии, элементного анализа. Изучены сорбционные свойства синтезированных полимеров по отношению к ионам тяжелых и переходных металлов.

Ключевые слова: сорбент, химическая модификация, радикальная сополимеризация, комплекс образующая способность, тяжелые металлы, переходные металлы, статическая обменная емкость.

\section{Introduction}

Treatment of waste water, liquids and gases directed on decrease the negative impacts of human economic activity on the environment connected with application of ion exchange. The synthesis, research and the use of chelating ion-exchange materialspolymer compounds with functional groups capable for forming cheated compounds with metal ions is one of the research areas. 
In a special interest are the new cost-waste or low-waste and combined ion exchange purification methods based on the use of promising ion exchangers and ion exchange units [1-2].

The heavy metals are main pollutants of waste water [3].

Heavy metals, especially cadmium, mercury, lead, zinc accumulates in plants. Consumption of plants, fish, water contaminated with heavy metals are the main sources of these pollutants penetrate into the humans body.

Therefore, the purification of waste-and industrial water from toxic ions is significant task [4-6]. In this regard the complexing sorbents are perspective.

The range of ion exchangers is very broad but the practical use of sorbents requires that they had a high exchange capacity for metal ions, satisfactory kinetics and dynamics of adsorption and have mechanically and chemically stable.
The chelating polymers with ionic groups capable to form chelate compounds with metal cations are most perspective [7].

The purpose of this work is preparation of new chelating ion exchanges and study of their sorption properties with respect to ions certain heavy metals.

\section{Experiment}

By the chemical modification of chloromethylatedstyrene-divinylbenzene with famous analytical reagent - nicotinamide a spatial structured ion exchangers are obtained.

The high mechanical strength, chemical and thermal stability and resistance to oxidative degradation, combining with sufficient activity in the substitution reactions of the hydrogen atoms of the styrene phenylnucleus with divinylbenzene (DVB) allows to obtain a chelating ion exchangers.<smiles></smiles><smiles></smiles>

As an initial product the industrial samples of chloromethylated copolymers of styrene with 2,4 , $8,10 \%$ DVB gel and macroporous structure with a chlorine content 17 - $21 \%$ was used.

To find the conditions for introduction of the maximum number of nicotinamide groups into the polymer the effect of solvents, the ratio of chloromethyl groups and analytical reagent duration and process temperature were investigated. The degree of chloromethylated copolymer conversion was studied by elemental analysis. Among the used solvents, dimethyl- formamide was the most suitable. It allows to obtaine the polymer with the highest content of nicotinamide groups. Study the ratio of a reactive components showed that the highest degree of conversion is achieved in the presence of critical excess of analytical reagent per one basis -mole of chloromethylated copolymer of styrene and DVB.

The study of influence of temperature (Figure 1a) and heating time (Figure 1b) showed that the highest degree of conversion is achieved at $100^{\circ} \mathrm{C}$ (nitrogen content - 5.7\%), the reaction runs during 7 hours. 


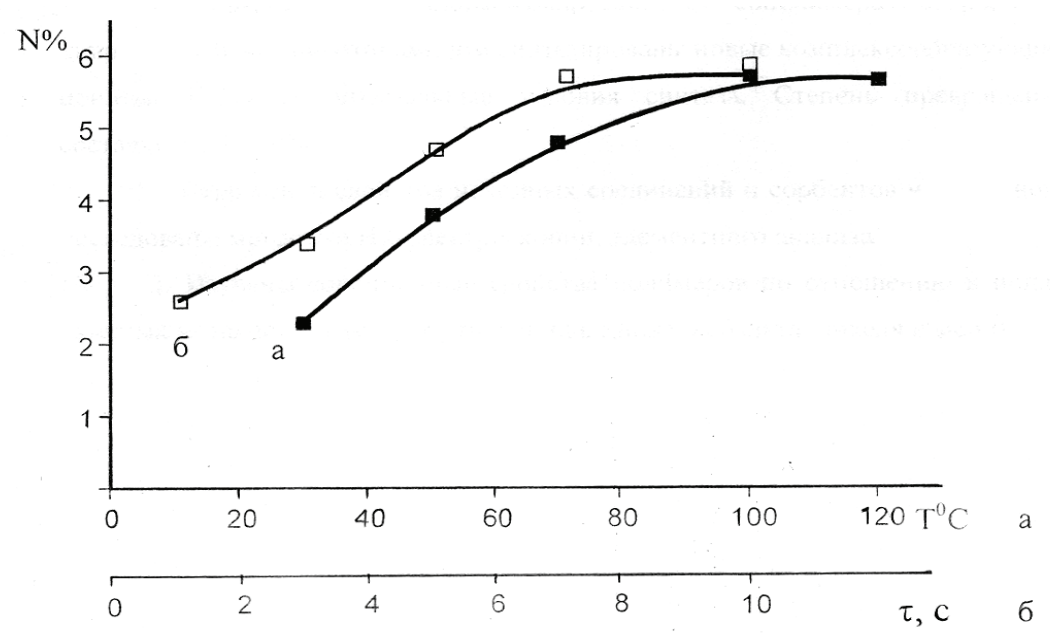

Figure 1 - Dependence of the introducted nicotinamide groups quantity on the temperature (a) and process duration (b)

Copolymers of o-, m- and p-MABK with 2methyl-5-vinylpyridine (2M5VP) obtained by radical copolymerization MABK with $2 \mathrm{M} 5 \mathrm{VP}$ at equimolar ratios of the initial monomer mixture (50:50 $\mathrm{mol} \%)$, initiator concentration dimethylazoizooildacids (DAA) $5 \cdot 10^{-3}$ and monomer $1,4 \mathrm{~mol} / \mathrm{l}$ at $333 \mathrm{~K}$ in ethanol and dimethylformamide (DMF) were purified from unreacted monomers by two fold reprecipitation of
DMF solution in ethyl acetate, followed by several washing with acetone and then dried under vacuum till constant weight. The obtained copolymers are brown, soluble in DMF, ethanol, acetone and aqueous alkaline solution.

The structure of metacryloilaminobenzoic acids copolymer with 2-methyl-5-vinylpyridine (MABA-2M5VP) can be schematically represented as:<smiles>CCCCCC(C)C(=O)Nc1cccc(C(=O)O)c1</smiles>

Copolymers based on various isomers MABA2M5VP are the bulk, light brown colored materials soluble in DMF, ethanol, acetone.

The structure of synthesized sorbents was analized by IR spectroscopy. When interaction of the chloromethylated copolymer with nicotinamide the intensity of absorbtion bands $\left(\mathrm{cm}^{-1}\right)$ of $\mathrm{CH}_{2}$ $\mathrm{Cl}$ - groups (1270 and 670) significantly reduced and frequencies in range 3350,3225 and 3160 appears. Also the bands at 1680 and $1610 \mathrm{~cm}^{-1}$ corresponding to amide I and amide II appears.

In the spectra of synthesized copolymers based on MABA isomers with $2 \mathrm{M} 5 \mathrm{MR}$ characteristic absorption bands of $\left(\mathrm{cm}^{-1}\right) \mathrm{COOH}$ groups: valence (1820), symmetrical (1405-1410), asymmetric (1650) and deformation vibrations of NH-relations (1340) were detected. The frequencies $v_{c=0}$ are presented at $1740 \mathrm{~cm}^{-1}$. The spectrometry scale was graduated by absorbtion bands of polystyrene film. The accuracy of determination of wave number for narrow bands in range $4000-2000 \mathrm{~cm}^{-1}$ was \pm 6 $\mathrm{cm}^{-1}$, and in range $2000-400 \mathrm{~cm}^{-1}- \pm 3 \mathrm{~cm}^{-1}$. For synthesized sorbent with nicotinamide group was defined the static exchange capacity (SEC) for some heavy metal ions (meq/g) (Table 1): 
Table 1 -of sinthesized sorbent by heavy metal ions

\begin{tabular}{|l|lllllll|}
\hline \multirow{2}{*}{ Sorbent } & \multicolumn{7}{|c|}{ SEC, meq/ g } \\
\cline { 2 - 7 } & $\mathrm{Cd}^{2+}$ & $\mathrm{Pb}^{2+}$ & $\mathrm{Zn}^{2+}$ & $\mathrm{Hg}^{2+}$ & $\mathrm{Co}^{2+}$ & $\mathrm{Ni}^{2+}$ & $\mathrm{Cu}^{2+}$ \\
\hline $\begin{array}{l}\text { The macroporous structured sorbent } \\
\text { with nicotinamide group }\end{array}$ & 1,8 & 1,8 & 1,1 & 3 & 1,4 & 1,5 & 1,65 \\
\hline
\end{tabular}

\section{Results and discussion}

Using chelating ion exchangers the most favorable conditions for the formation of complexes are created [7]. The dependence of the metal ions exchange capacity on acid solutions were studied. $\mathrm{pH}$ of the metal salt solutions was changed from 3 to 8 . A further increase of $\mathrm{pH}$ leads to the formation of the corresponding metal hydroxide precipitation. Figure 2 shows the dependence of the synthesized by the cadmium, lead, and zinc ions sorbent exchange capacity on the $\mathrm{pH}$ of solution. The figure shows that with the grows of $\mathrm{pH}$ the static exchange capacity (SEC) $(\mathrm{meq} / \mathrm{g})$ increases and reaches of maximum degrees for the $\mathrm{Cd}^{2+}$ ions at $\mathrm{pH} 5.9(2.6 \mathrm{meq} / \mathrm{g})$; for $\mathrm{Zn}^{2+}$ ions at $\mathrm{pH} 5.7(1.29 \mathrm{meq} / \mathrm{g})$ and $\mathrm{Pb}^{2+}$ ions at $\mathrm{pH} 4.7$ (2.17 meq/g).

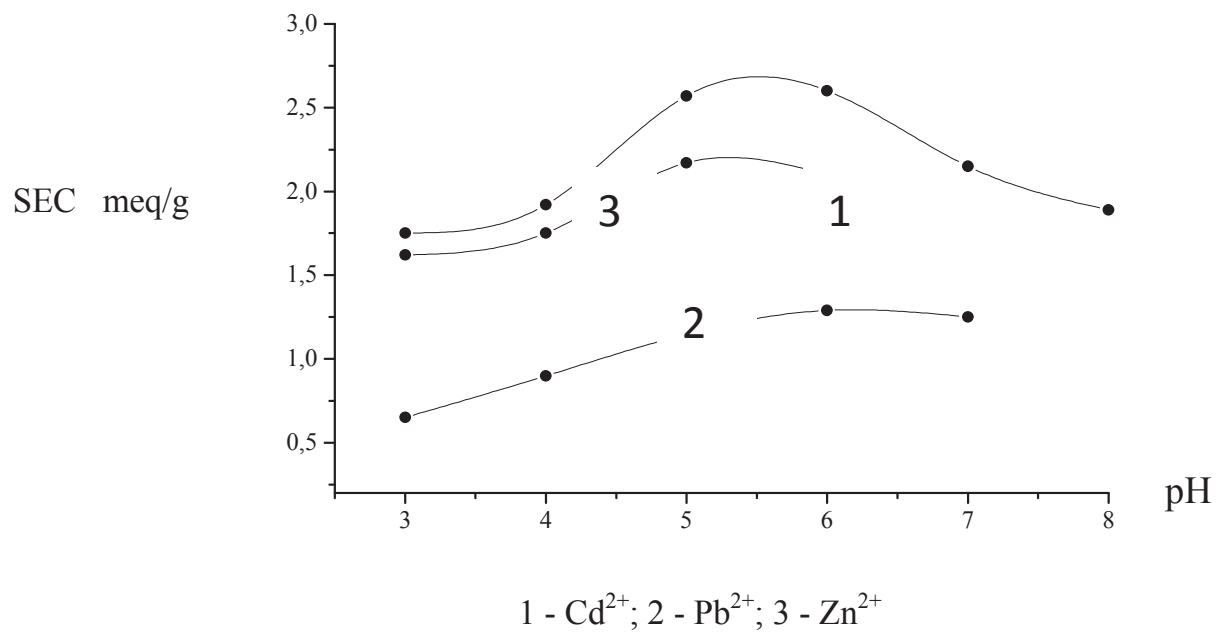

Figure 2 - The dependence of the sorbent static exchange capacity with nicotinamide groups at $\mathrm{Cd}^{2+} ; \mathrm{Pb}^{2+} ; \mathrm{Zn}^{2+}$ ions on the $\mathrm{pH}$ of solution

These data show that polymer with nicotinamide groups has selectivity for cadmium ions.

An ion-exchange property of obtained polyampholytes was studied for cations of copper, zinc, nickel, cobalt, cadmium, and manganese at different values of medium $\mathrm{pH}$ and concentration of metal ions in static conditions. Exchange capacity of the polyelectrolyte by metal ions was determined by the difference in the concentrations of metal ions in the equilibrium solution before and after the trilonometric contact with the ion exchanger. For determinion the equilibrium exchange capacity of the copolymers the $0.05 \mathrm{~N}$ solution of nitrate salts of metals in ammonium- acetate buffer solution with the $\mathrm{pH}$ range from 4 to 7 was used. Ion content in the solution before and after sorption was determined by complex metric method with use of appropriate indicators. A significant impact on the adsorption capacity of the polymer has the location of the active group in the phenyl ring of the copolymer. The polyamfolyte based on MABA para-isomer has a higher SEC than the ortho-isomer. This is quite understandable since the access to the $\mathrm{COOH}$-group in the paraposition is maximally facilitated. It was experimentally proved that they are responsible for formation of coordination relations with transition metal ions (Figure 3). 

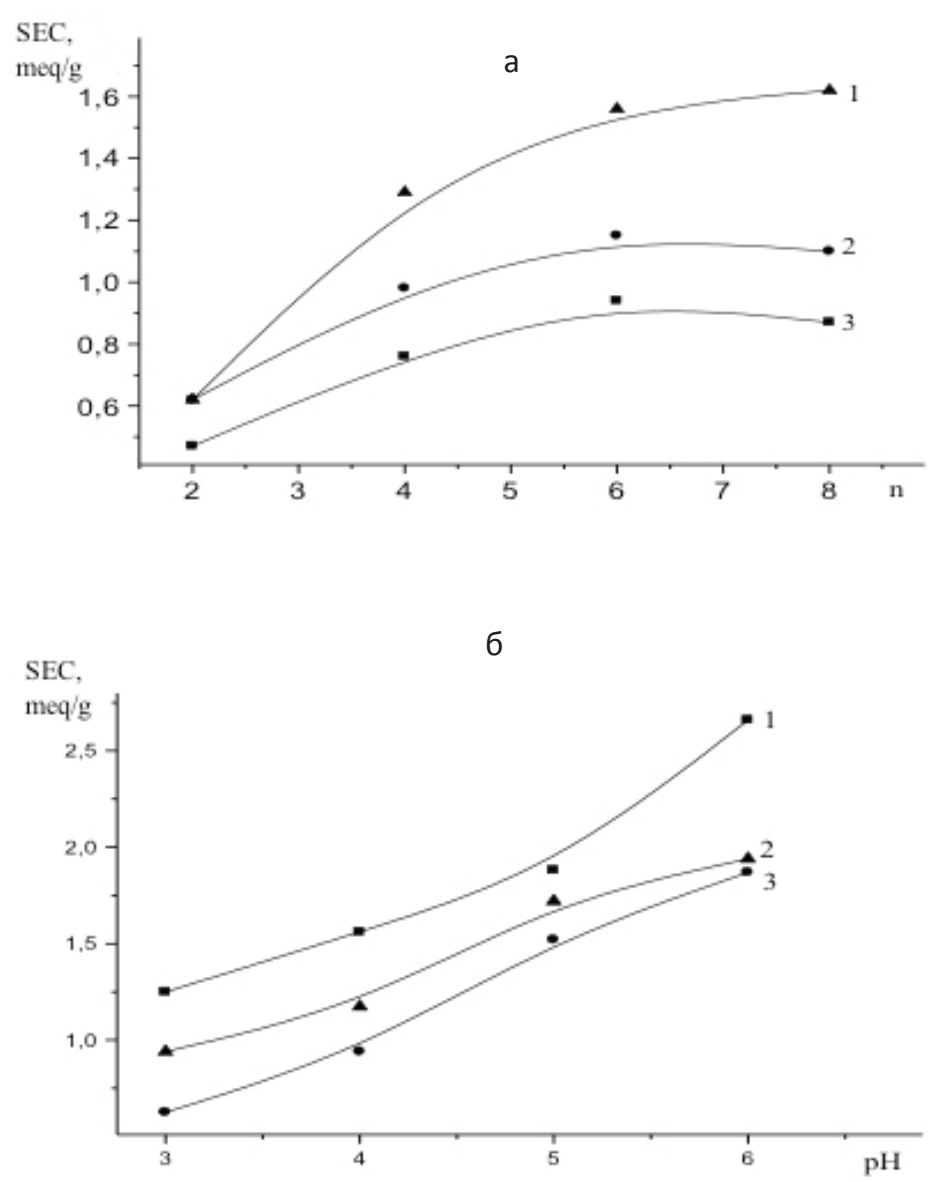

$p$-MABA (1); $m$-MABA (2); $o$-MABA (3); $\mathrm{Me}^{2+}-\mathrm{Cu}^{2+}$; the concentration of copper ions (a); $\mathrm{pH}($ (б).

Figure 3 - The dependence of the MABA-2M5VP polyampholytes sorption capacity on the concentration of copper ions and the $\mathrm{pH}$ of the medium

When concentrations of the extracted substrate increase with the ion exchange the process of complexes formation results to compression of the macromolecule. In this case the sorption proceeds only on the surface of the macromolecular coil and the diffusion of the growing component in the inner layers of the copolymer due to steric factors becomes difficult.

Data about changes in SEC of copolymers of metacryloilaminobenzoic acids with 2-methyl-5vinylpyridine on solution $\mathrm{pH}$ showed that at low $\mathrm{pH}$ the binding degree of metal ions is low (SOE $\mathrm{Cu}=0.5-2 \mathrm{meq} / \mathrm{g}$ at $\mathrm{pH} 2$ and 3) then with the $\mathrm{pH}$ increase the capacity rises sharply (to $2-2.6$ $\mathrm{meq} / \mathrm{g}$ ) with following slowing down. The maximal extraction of metal ions from solution is achieved at $\mathrm{pH}$ 5-6. A further increase of $\mathrm{pH}$ results to the formation of hydroxide precipitations and basic salts. Therefore research at $\mathrm{pH} 7$ do not carried out.

Table 2 shows the SEC of MABA homopolymer and copolymer polyelectrolytes obtained in optimal sorption conditions.

MABA copolymers with 2-methyl-5vinylpyridine have a higher sorption characteristics than homopolymers. Exchange capacity of copolymers higher than for of homopolymers in 1,1-3 times due to the additional complex formation of pyridine nitrogen of 2-methyl-5vinylpyridine with metal ions. The high values of SEC of polyampholytes for metal ions is caused by side effects such as formation of insoluble coordination-bounded forms of metal ions with functional macromolecule groups during the extraction process, the accumulation of metal ions on the polymer surface. 
Table 2 - Chelating properties of polyampholytes with transition metal ions $\left(\mathrm{pH}=5, \mathrm{C}_{\mathrm{Me}^{+}}=0.08 \mathrm{~mol} / \mathrm{L}\right)$

\begin{tabular}{|c|c|c|c|c|c|c|}
\hline \multirow[b]{2}{*}{ Polyelectrolyte } & \multicolumn{6}{|c|}{ SEC, meq/g } \\
\hline & $\mathrm{Cu}^{2+}$ & $\mathrm{Zn}^{2+}$ & $\mathrm{Ni}^{2+}$ & $\mathrm{Mn}^{2+}$ & $\mathrm{Co}^{2+}$ & $\mathrm{Cd}^{2+}$ \\
\hline$n$-MABA-2M5VP & 8,08 & 6,33 & 3,37 & 2,43 & 2,27 & 4,28 \\
\hline$M$ - MABA-2M5VP & 5,92 & 3,37 & 3,46 & 2,86 & 3,35 & 2,35 \\
\hline$o$ - MABA-2M5VP & 4,32 & 3,54 & 2,70 & 1,84 & 1,67 & 1,53 \\
\hline Poly- $n$ - MABA & 3,65 & 4,50 & 1,15 & 3,37 & 2,20 & 2,25 \\
\hline
\end{tabular}

Copolymers have a high rate of ion exchange and high sorption ability with respect to $\mathrm{Cu}^{2+}, \mathrm{Zn}^{2+}$, $\mathrm{Ni}^{2+}, \mathrm{Mn}^{2+}, \mathrm{Co}^{2+}, \mathrm{Cd}^{2+}$ ions, so can be used for extraction, concentration and selective isolation from solutions of transition metal ions. So, high macromolecule mobility creates less steric hindrance for metal ions sorption and complexing. The optimal conditions for the process is found out to have ligand : metal ion ratio $=1: 6$ and $\mathrm{pH}=5-6$.
SEC amount to $1,5-8,0 \mathrm{meq} / \mathrm{g}$ for these ions.

\section{Conclusion}

So, the new sorbent with nicotinamide groups, copolymers based on MABA with 2M5VP isomers was synthesized, also a new opportunity of their uses for heavy and transition metal ions sorption was investigated.

\section{References}

1 Ashirov A. Ion exchange purification of waste water, solutions and gases. (Rus).- L: Khimiya, 1993. - P. 291.

2 Senyavin M.M. Ion exchange in technology and analysis of inorganic substances. (Rus). - M.: Khimiya, 2000. - P. 202.

3 Bokris O.M. Chemistry of enviroment. (Rus).- M.: Khimiya, 1982. - P. 670.

4 Ergozhin E.E., Tausarova B.R. Soluble polyelectrolytes. - Alma-Ata: Gylym, 1991. - P.222.

5 Myasoedova G.B., Savvin S.B. Chelating sorbents (Rus).- M: Nauka, 1994. - P. 58-62.

6 Skurlatov Yu.I., Duka G.G., Miziti A. Introduction to the ecological chemistry (Rus). M.: Vysshaya shkola, 2004. P. 400 .

7 Umland F., Yansen A. Complex compounds in analytical chemistry. (Rus). - M.: Mir, 1995. - P. 256. 